\title{
Menghadirkan Guru Agama Berwawasan Kebangsaan di Daerah Perbatasan
}

\author{
Muhamad Murtadlo \\ Peneliti Badan Litbang dan Diklat Kementerian Agama RI \\ tadho25@gmail.com
}

\begin{abstract}
Abstrak
Menghadapi masuknya paham-paham transnasional yang berpotensi memecah belah, lembaga pendidikan agama dan keagamaan daerah tertinggal dan perbatasan negara membutuhkan tenaga pendidik agama/keagamaan yang berwawasan kebangsaan yang memadai. Kekosongan orang yang memahami agama secara memadaim, menyebabkan pendidikan agama diajarkan oleh orang seadanya. Dengan pengetahuan agama seadanya, maka pembelajaran agama lebih cenderung bersifat ritualistik. Masing-masing kelompok agama hanya mengajarkan agama untuk kepentingan kelompoknya sendiri. Permasalahan yang menghantui terkait dengan kerukunan agama di daerah perbatasan adalah pengelompokan sosial atas nama agama yang potensial menimbulkan rasa iri apabila salah satu kelompok mengalami kemajuan.

Kata-kata kunci: Perbatasan Negara, Guru Agama, Wawasan Kebangsaan
\end{abstract}

Globalisasi informasi disebut-sebut oleh para pemerhati sebagai salah satu tantangan besar bagi dunia pendidikan, termasuk pendidikan agama dan keagamaan. Para pemerhati mempunyai pendapat yang beragam mengenai pendidikan dalam konteks globalisasi (Kazamias, 2001; Menon, 2007; Tilaar, 1999: 145-147; Mastuhu, 2003: 10; Sirozi, 2005: 189;). Diantara pandangan para pemerhati, ada yang bersikap pesimis dan ada juga yang optimis melihat pendidikan dalam konteks globalisasi. Salah satu yang perlu dicermati terkait globalisasi informasi di bidang keagamaan adalah datangnya paham-paham transnasional yang tidak jarang melahirkan paham radikalisme sektoral dan berpotensi membenturkan antar kelompok keagamaan di masyarakat. Indonesia yang mempunyai keragamaan suku, bahasa serta agama perlu memperhatikan secara serius kemungkinan dampak negatif yang muncul, terlebih dampaknya di daerah-daerah tertinggal dan perbatasan negara.

Menghadapi masuknya pahampaham transnasional yang berpotensi memecah belah, menuruk saya, lembaga pendidikan agama dan keagamaan daerah tertinggal dan perbatasan negara membutuhkan tenaga pendidik agama/keagamaan yang berwawasan kebangsaan yang memadai. Kesimpulan ini saya peroleh dari berbagai riset dan kunjungan di berbagai titik lokasi yang disebut daerah/suku tertinggal seperti Suku Anak Dalam di Provinsi Jambi, Suku Baduy Kabupaten Lebak Banten dan Suku Kokoda di Sorong Papua Barat; serta penelitian saya di daerah-daerah perbatasan negara seperti di distrik Sota, Merauke, dan di Pulau Waigeo, Raja Ampat. Di daerahdaerah seperti ini, kebanyakan pendidik agama diperankan oleh pendidik agama lokal yang seadanya dan wilayah seperti ini sangat rentan dimasuki paham-paham keagamaan yang dibawa pendatang yang kurang berwawasan kebangsaan.

Pada Suku Anak Dalam di Provinsi Jambi, misalnya, pendidikan agama yang ditawarkan oleh masyarakat luar (pendatang) dirasa oleh Suku Anak Dalam lebih banyak dilakukan dengan cara pendekatan orang kota. Di sisi lain, membiarkan mereka dengan pengetahuan dan keyakinannya, membuat mereka menjadi kelompok sosial yang semakin tertinggal dan terbelakang. Pendekatan yang tidak tepat, justru membuat mereka resisten terhadap penyuluhan agama. Bagi mereka, untuk menjadi orang yang semakin beragama seperti terasa ajakan (tuntutan) 
untuk meninggalkan kebudayaan tradisional mereka dan menjadi orang beradab sebagaimana orang kota seperti hidup harus menetap di wilayah tertentu. Padahal mereka selama ini cukup menikmati hidup dengan cara berpindahpindah (nomaden) yang dianggapnya sebagai bentuk keseimbangan tersendiri bagi keselarasan lingkungan.

Suasana yang hampir sama dengan warna yang berbeda juga dirasakan oleh suku Baduy di Lebak Banten. Suku Baduy adalah sebuah suku yang menganggap diri mereka sebagai penjaga nilai asli nenek moyang suku Sunda. Mereka sering disebut sebagai sebagai penganut kepercayaan Sunda Wiwitan. Mereka yang terbiasa hidup dan berkeyakinan belajar langsung dari apa yang disediakan oleh alam sekitar dan menghadapinya tanpa tehnologi tertentu, termasuk dalam keyakinan mereka, akan merasa dijauhkan dengan pandangan mereka ketika pendidik/penyuluh agama masuk mengajar mereka. Mereka seperti dipaksa menerima metode atau tehnik beragama dengan cara pendidikan modern seperti diajarkan dengan sistem kelas, memakai buku dan sebagainya. Padahal bagi mereka adalah pantangan untuk menerima peradaban modern dalam kehidupan mereka.

Lain lagi yang dirasakan oleh Suku Kokoda di Sorong Selatan. Suku Kokoda adalah sebuah suku Papua asli yang berasal dari Kabupaten Sorong Selatan. Seiring perkembangan kota di Papua, sebagian suku Kokoda bermigrasi ke kota dan membuat kantong-kantong baru di kota. Para pendidik/penyuluh dalam mengajarkan agama pada kelompok ini dirasakan oleh mererka kebanyakan hanya datang dan pergi. Mereka dikunjungi dan diberi bantuan setelah itu para pendidik/penyuluh itu pergi. Mereka membutuhkan pendidik/penyuluh agama yang mau tinggal bersama dan diantara mereka.

Sementara itu, pada masyarakat perbatasan negara seperti di distrik Sota Merauke, karena kekosongan orang yang memahami agama secara memadai maka pendidikan agama diajarkan oleh orang seadanya. Di daerah ini, pendidikan agama Islam, misalnya, diajarkan oleh seorang transmigran yang kebetulan alumni SMA. Karena orang ini dianggap yang paling mengerti agama, maka diminta untuk mengajarkan agama. Dengan pengetahuan agama seadanya, maka pembelajaran agama lebih cenderung bersifat ritualistik. Pendidik agama untuk masing-masing kelompok agama hanya mengajarkan agama untuk masing-masing kelompok agama saja. Belum ada agamawan di wilayah itu yang mempunyai kapasitas pengayom semua agama dan bisa menjembatani komunikasi antar agama.

Permasalahan yang menghantui terkait dengan kerukunan agama di daerah perbatasan seperti Merauke ini adalah pengelompokan sosial atas nama agama. Penduduk lokal identik dengan Katholik atau Kristen, sedangkan pendatang adalah islam. Pengelompokan sosial seperti ini bisa berbahaya bila salah satu kelompok kemudian bisa lebih maju dari pada yang lain. Pendatang yang kebetulan adalah para transmigran dari jawa biasanya mempunyai keuletan dalam bekerja untuk menyambung hidup di daerah itu. Lama-lama secara sosial ekonomi, para pendatang banyak lebih berhasil hidupnya dibandingkan penduduk lokal.

Melihat kemajuan para transmigran ini, Pemerintah daerah Merauke yang melihat modal para transmigran ini berupa sawah atau ladang dan rumah kavling, maka untuk memotivasi warga lokal, mereka dibuatkan rumah kavling. Terobosan ini bukan tanpa masalah, karena dengan memberikan penduduk fasilitas sebagaimana yang didapatkan para transmigran ternyata justru membuat penduduk lokal termanjakan. Tanpa kerja keras mereka toh bisa menikmati rumah kavling, sementara mental bekerja di kalangan penduduk lokal belum terbangun. Ini mungkin kerugian yang dimiliki oleh penduduk lokal.

Kerugian yang dirasakan oleh pendatang akibat potensi kecemburuan 
warga lokal juga ada. Di kalangan muda pendatang, mulai muncul pemahaman kalau mau maju harus keluar dari daerah itu misalnya mereka melanjutkan pendidikan ke kota atau ke jawa atau Sulawesi atau daerah lain. Kerawanan yang disebabkan adanya kesenjangan yang makin menganga antara kelompok pendatang dan penduduk lokal, menyebabkan para anak muda memilih pergi dari daerah situ untuk belajar atau memperbaiki nasib yang lebih baik. Ketika mereka menjadi sarjana, kebanyakan mereka enggan untuk kembali ke daerah itu. Alih-alih dari pada memperkeruh suasana mending cari kehidupan yang lebih baik di tempat lain.

Barangkali kita bisa berandai-andai, seandainya saja ada penduduk pribumi yang menjadi mualaf dan bersedia masuk Islam. Mungkin rasa cemburu yang menimbulkan kontra produksi dari berbagai sisi itu tak perlu terjadi. Ada memang satu dua orang lokal menikah dengan pendatang, namun sayang biasanya yang melakukan atau berani menikah dengan pendatang ini adalah mereka yang secara agama memang tidak kuat. Akibatnya ketika masuk Islam, mereka juga termasuk orang yang kurang taat beragama. Agama ya sekedar agama. Jadi berharap kepada mereka untuk melakukan perbaikan keadaan juga jauh panggang daripada api. Artinya , kita tidak bisa berharap dengan orang-orang model begitu.

Namun apapun kenyataannya, perencanaan terkait perkembangan keagamaan perlu dilakukan. Bukan sebaliknya, muncul anggapan orang daripada penguatan agama berimplikasi pada kerawanan sosial, maka sebaiknya penguatan agama melalui pendidikan tidak perlu dilakukan. Mungkin ada sebagian pejabat daerah yang berpandangan seperti itu, sehingga pendidikan agama menjadi tidak prioritas. Namun mengingat agama adalah persoalan pribadi yang bisa jadi sumber daya dinamis, maka sekali lagi perekayaasaan terkait kehidupan keagamaan perlu terus dilakukan. Seiring dengan usaha pembangunan daerah yang melibatkan spirit keagamaan sebagai potensi pendorongnya.

Sejauh ini potensi kerusuhan antar agama di Distrik Sota Merauke memang tidak sampai meledak menjadi kerusuhan sosial. Hal itu bisa jadi karena secara kebetulan di distrik Sota ada pos tentara yang cukup kuat, sehingga riak sekecil apapun di masyarakat akan dengan mudah ditangani. Namun mengandalkan kekuatan militer dalam kedewasaan masyarakat beragama ke depan juga kurang tepat. Maka sekali lagi model pendidikan agama yang mendorong pada kedewasaan dalam berelasi dengan umat beragama lain perlu terus dipupuk.

Demikian juga di daerah perbatasan di Pulau Waigeo, Raja Ampat. Sebuah daerah yang berbatasan laut dengan Republik Nauru. Di daerah ini pendidikan agama harus berhadapan dengan hadirnya investor yang berdatangan seiring keinginan kuat pemerintah pusat menjadikan daerah ini menjadi tujuan wisata nasional, bahkan internasional. Ketersediaan guru agama yang terbatas, dan pendidikan masyarakat yang rendah menyebabkan orang lokal serasa tidak bisa bersaing dengan kehadiran pendatang. Hal ini menyebabkan adanya proses termaginalisasikannya penduduk lokal.

Tanpa mengurangi apresiasi kita terhadap para perintis awal pendidikan agama di daerah-daerah ini, mereka pada umumnya masih menekankan pendidikan agama yang masih menekankan sisi ritualistik beragama. Akibatnya kemajuan ritualistik yang diwujudkan dengan maraknya pembangunan rumah ibadah baru dan kegiatan syiar agama tertentu terkadang dianggap ancaman bagi kepercayaan lokal daerah tertinggal atau pemeluk agama lain di daerah perbatasan. Hal-hal seperti ini berpotensi menimbulkan kerawanan sosial tertentu yang sebenarnya tidak perlu terjadi.

Untuk menjawab persoalan itu, sudah waktunya kementerian agama mulai memikirkan perlunya menghadirkan di daerah-daerah tertinggal dan daerah-daerah perbatasan pendidik/penyuluh agama yang 
memiliki kompetensi memadai dan berwawasan kebangsaan. Prasyarat seperti itu diperlukan agar supaya pendidikan agama dan keagamaan sebagai pembentuk moral dan karakter di daerah-daerah seperti itu mempunyai daya dongkrak kemajuan dalam konteks NKRI, dan tidak sebaliknya pendidikan agama dan keagamaan yang berpotensi melahirkan konflik sosial.[] 